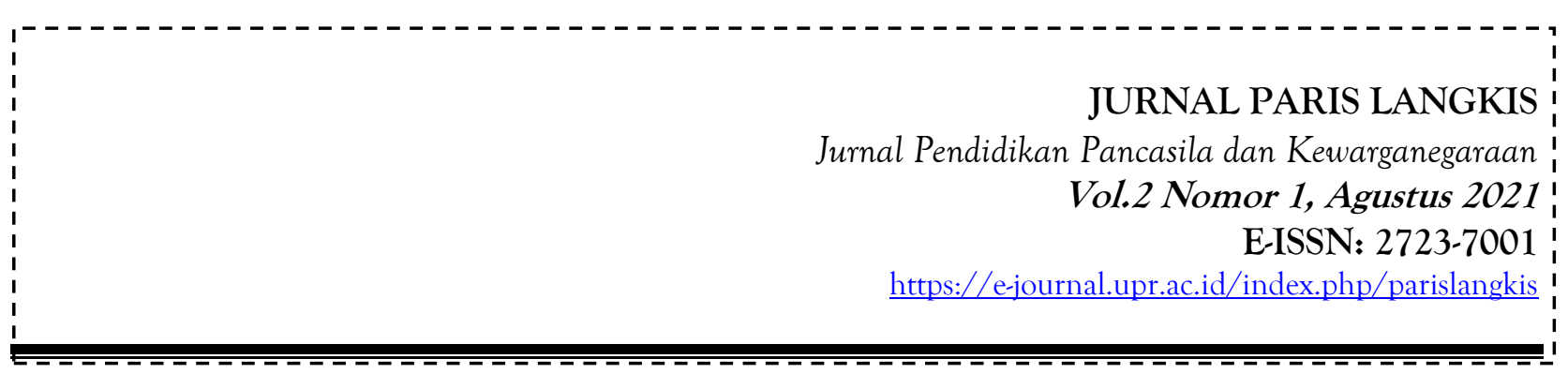

\title{
PENGARUH INTERAKSI MODEL PEMBELAJARAN BERBASIS PROYEK DAN KEMAMPUAN BERPIKIR KRITIS TERHADAP HASIL BELAJAR PPKN DI KELAS VII SMP NEGERI 11 KOTA SERANG
}

\author{
Yeti Nurhayati ${ }^{1}$, Suherman ${ }^{2}$, Sudadio $^{3}$
}

\begin{abstract}
Abstrak
Penelitian ini berawal dari observasi di sekolah bahwa dalam proses pembelajaran PPKN belum sepenuhnya mencapai tujuan pembelajaran dan hasil belajar yang maksimal. Kurang maksimalnya guru dalam mengemas kegiatan pembelajaran PPKn dengan tepat akan berakibat terhadap ketidakmaksimalan hasil belajar peserta didik. Berdasarkan hasil evaluasi belajar peserta didik dalam pembelajaran PPKn diketahui bahwa ketidakberhasilan itu disebabkan oleh beberapa hal, antara lain metode ceramah yang digunakan menyebabkan pembelajaran lebih berfokus pada guru sehingga peserta didik menjadi pasif, peserta didik kurang antusias mengikuti proses pembelajaran, bahkan ada beberapa peserta didik yang mengantuk. Dari permasalahan yang ada, diperlukan suatu terobosan baru yang menuntut

guru untuk menciptakan suatu kegiatan pembelajaran yang menyenangkan, guru juga dituntut untuk memiliki kompetensi memilih model pembelajaran dengan karakteristik kompetensi dasar. Penelitian ini bertujuan untuk mendeskripsikan dan menganalisis pengaruh interaksi antara model pembelajaran berbasis proyek dan kemampuan berpikir kritis terhadap hasil belajar PPKn di kelas VII SMP Negeri 11 Kota Serang.

Metode dalam peneltian ini menggunakan metode quasi eksperimen dengan rancangan desain treatment by level $2 \times 2$ atau desain faktorial 2 X 2. Hasil penelitian diambil dari uji hipotesis. Uji hipotesis dilakukan untuk mengetahui apakah hipotesis yang diajukan dalam penelitian ini diterima atau ditolak maka digunakan analysis of varian two ways (Anova dua jalur ).

Hasil penelitian ini dapat terlihat dalam Tests of Between-Subjects Effects di atas, didapatkan Kesimpulan Sebagai Berikut : diperoleh nilai Signifikansi (sig.) sebesar 0,013 atau lebih kecil dari 0,05 maka artinya hipotesis yang menyatakan bahwa ada perbedaan Hasil Belajar PPKn berdasarkan Kemampuan Berpikir Kritis dapat diterima. Untuk pengujian signifikasi, berdasarkan tabel Tests of Between-Subjects Effects di atas, didapatkan nilai $F_{\text {hitung }}$ untuk masing-masing variabel lebih besar dari $F_{\text {tabel }}$ pada taraf signifikansi $5 \%$ dimana $\mathrm{F}_{\text {tabel }}=4.091$ yang berarti dapat disimpulkan terdapat pengaruh secara signifikan interaksi antara model Pembelajaran Berbasis Proyek dan Kemampuan Berpikir Kritis peserta didik terhadap Hasil Belajar PPKn peserta didik.
\end{abstract}

Kata kunci : Model Pembelajaran Berbasis Proyek, Kemampuan Berpikir Kritis, Hasil Belajar PPKn.

\section{Paris Langkis}

Vol.2 Nomor 1, Agustus 2021 


\section{A. PENDAHULUAN}

Pembelajaran Pendidikan Pancasila dan Kewarganegaraan (PPKn) selama ini cenderung membosankan, tidak menarik dan tidak menyenangkan sehingga kurang membangun motivasi peserta didik. Padahal idealnya, pembelajaran harus menyentuh kognitif, afektif, psikomotor. psikomotorik, maka perlu mengatur strategi pembelajaran PPKn melalui upaya peningkatan semangat belajar yang sesuai dengan generasi Z. Rendahnya motivasi belajar PPKn menurutnya karena pemakaian metode ceramah, memposisikan peserta didik pasif, tidak responsif terhadap materi serta mengabaikan muatan dan visi.

Pembelajaran PPKn memfasilitasi peserta didik untuk mengembangkan 4C'S yaitu critical thinking, creativity, colaboration dan communiacation skills. Salah satu kompetensi yang penting dikembangkan di abad 21 adalah critical thinking skills. Oleh karena itu proses pembelajaran diharapkan dapat melatih peserta didik untuk berpikir kritis (Pratama \& Karakter, 2021). Peserta didik mengasah keterampilan berpikir kritisnya jika dihadapkan dengan suatu persoalan dalam kehidupan sehari-hari. Proses pembelajaran yang mengasah keterampilan berpikir kritis ini tidak terlepas dari peran guru sebagai fasilitator. Kenyataannya guru masih mendominasi pembelajaran (teacher centered) dan kurang mengembangkan keterampilan berpikir kritis. Hal ini sejalan dengan pendapat Hairida (2016) yang menyatakan bahwa proses pembelajaran yang berpusat pada guru tidak dapat meningkatkan keterampilan berpikir kritis peserta didik. Berpikir kritis merupakan proses berpikir kompleks yang terdiri atas interpretasi, analisis, inferensi, evaluasi, eksplanasi, dan pengaturan diri (Wartono, dkk., 2018).

Berdasarkan Permendikbud Nomor 103 tahun 2014, pada kurikulum 2013, tuntutan pada tiap kompetensi meliputi tiga ranah, yaitu ranah pengetahuan, ranah sikap dan ranah ketrampilan. Kurikulum ini juga 7 mengupayakan peningkatan keseimbangan, kesinambungan dan keterkaitan antara hard skills dan soft skills. Sehingga dalam proses pembelajaran yang dilakukan dapat memunculkan 18 nilai karakter yaitu : religius, jujur, toleransi, disiplin, kerja keras, kreatif, mandiri, demokratis, rasa ingin tahu, semangat kebangsaan dan nasionalisme, cinta tanah air, menghargai prestasi, komunikatif, cinta damai, gemar membaca, peduli lingkungan, peduli sosial dan tanggung jawab. Nilai tersebut dapat muncul pada peserta didik jika guru memiliki kemampuan untuk mengeksplorasi peserta didik dengan mengajak peserta didik terlibat secara aktif dalam pembelajaran yang kreatif, menarik, menyenangkan, inovatif dan kekinian sehingga peserta didik ingin berpartisipasi dan berperan aktif. Hal ini dikarenakan peserta didik senang dan tidak mau terlewatkan setiap momen yang terjadi pada proses pembelajaran.

Perlu ada penerapan pendekatan lain yang lebih kreatif dan inovatif yang dapat membantu peserta didik dan guru dalam memunculkan rasa ingin terus belajar dan mengetahui lebih banyak dan lebih jauh lagi. Memunculkan rasa membutuhkan dan berusaha untuk mengimplementasikan dalam kehidupan baik diri maupun lingkungan peserta didik tentang materi dari pembelajaran PPKn.

Pendekatan pembelajaran yang dirancang hendaknya kontekstual sesuai dengan tuntutan pada kompetensi inti yang ada pada kurikulum 2013 sehingga akan menggali soft skills peserta didik secara optimal melalui rangkaian kegiatan dalam pembelajaran dan dapat

\section{Paris Langkis}

Vol.2 Nomor 1, Agustus 2021 
diimplementasikan dalam kehidupan sehari hari (Dewi Muryati; Endah Charolyna \& Ahmad Saefulloh, 2020). Munculnya soft skills dalam diri peserta didik, berasal dari proses kognitif yang terjadi selama proses pembelajaran sehingga akan terjadi akumulasi pada struktur kognitif peserta didik. Pembelajaran yang dialami oleh peserta didik dapat diterima sehingga akan bermakna bagi peserta didik dan akan selalu diingat dan melekat.

Keterampilan berpikir kritis dapat dilatihkan dan dibiasakan dalam pembelajaran (Irnin, 2016; Diani dkk., 2019). Peserta didik membangun, menemukan, dan mengembangkan pengetahuan melalui serangkaian aktivitas saintifik (Lia \& Derlina, 2016). Pembelajaran PPKn identik dengan kehidupan sosial peserta didik, namun kerap disajian membosankan dalam proses pembelajaran. Dalam penelitian kali ini, peneliti mencoba menyajikan contoh proses pembelajaran dengan model $\mathrm{PJBl}$ dan kemampuan berpikir kritis, dengan memanfaatkan barang yang ada disekitar peserta didik sebagai bahan pembuatan proyek.

Pembelajaran berbasis proyek merupakan pendekatan pembelajaran yang mengajarkan banyak strategi untuk menghadapi tantangan abad 21. Peserta didik membangun pengetahuan mereka sendiri melalui penyelidikan dengan bekerja sama untuk meneliti dan membuat proyek yang mencerminkan pengetahuan mereka (Adetya et al., 2021).

Rohmalina (2015: 214) dalam bukunya mengatakan bahwa model pembelajaran adalah alat bantu untuk mendeskripsikan suatu benda atau contoh agar mempermudah guru dalam menjelaskan objek dalam proses pembelajaran.

Sukamto, dkk dalam Hosnan (2016: 337) mengemukakan pendapat bahwa model pembelajaran adalah kerangka konseptual/ operasional, yang melukiskan prosedur yang sistematis dalam mengorganisasikan pengalaman belajar untuk mencapai tujuan belajar tertentu dan berfungsi sebagai pedoman bagi para pengajar dalam merencanakan, dan melaksanakan aktivitas pembelajaran.

Dari beberapa pendapat tersebut, maka dapat disimpulkan bahwa model sebagai suatu perencanaan atau suatu pola yang digunakan untuk mendesain polapola mengajar secara tatap muka dalam kelas yang merupakan kesatuan dari pendekatan, strategi, metode, teknik dan taktik pembelajaran. Setiap model mengarahkan pengajar untuk mendesain pembelajaran yang dapat membantu peserta didik untuk mencapai berbagai tujuan pembelajaran. Model pembelajaran ditunjukkan secara jelas kegiatan-kegiatan apa yang perlu dilakukan oleh guru atau peserta didik, bagaimana urutan kegiatan tersebut, dan tugas khusus apa yang dilakukan oleh peserta didik. Model pembelajaran bersifat penting dalam kegiatan pembelajaran. Model pembelajaran tersebut digunakan sebagai perencanaan pembelajaran yang memiliki landasan tetap untuk merancang suatu proses pembelajaran yang menarik dan inovatif sesuai dengan kondisi dan situasi peserta didik (Lana \& Karliani, 2021).

Model pembelajaran berbasis proyek berangkat dari pandangan konstruktivisme yang mengacu pada pendekatan kontekstual (Khamdi, 2007). Dengan demikian, pembelajaran berbasis proyek merupakan model pembelajaran yang menggunakan belajar kontekstual, dimana peserta didik berperan aktif untuk memecahkan masalah, mengambil keputusan, meneliti, mempresentasikan, dan membuat dokumen. Pembelajaran berbasis proyek dirancang untuk digunakan pada permasalahan kompleks yang diperlukan peserta didik dalam melakukan investigasi dan memahaminya. Pembelajaran berbasis proyek merupakan investigasi mendalam

\section{Paris Langkis}

Vol.2 Nomor 1, Agustus 2021 
tentang sebuah topik dunia nyata, hal ini akan berharga bagi atensi dan usaha peserta didik (Kemendikbud, 2014: 33).

Pembelajaran berbasis proyek juga sebagai model pembelajaran sistematis, mengikutsertakan peserta didik dalam mempelajari pengetahuan dan keahlian yang kompleks, pertanyaan autentik, dan perancangan produk dan tugas. Pembelajaran berbasis proyek dilakukan perseorangan atau kelompok yang dilaksanakan dalam jangka waktu tertentu guna menghasilkan produk, kemudian hasilnya ditampilkan atau dipresentasikan (Grand dalam Sumarmi, 2012: 171).

Prinsip yang mendasari adalah bahwa dengan aktivitas kompleks ini, kebanyakan proses pembelajaran yang terjadi disusun dengan baik. Pembelajaran berbasis proyek juga dapat meningkatkan keyakinan diri para peserta didik, motivasi untuk belajar, meningkatkan kemampuan kreatif, dan mengagumi diri sendiri (Sentyasa, 2006).

Fokus dari model pembelajaran berbasis proyek adalah proses dan produk. Proses yang dilakukan peserta didik berbentuk kegiatan-kegiatan seperti (1) menetapkan tema proyek, (2) konteks belajar, (3) merencanakan aktivitas, (4) memproses aktivitas, dan (5) penetapan aktivitas untuk menyelesaikan proyek (Sentyasa, 2006).

Situasi dalam proses tersebut dapat memancing kreativitas peserta didik dalam berpikir yang nantinya akan menghasilkan karya yang berupa (1) produk nyata, (2) peningkatan respon peserta didik terhadap segala perubahan dan akibat dari suatu situasi, (3) peningkatan kemampuan dalam manajemen diri, (4) peningkatan 26 kemampuan dalam mendemonstrasikan suatu proses kejadian, dan (5) kebiasaan melakukan evaluasi diri (Rasana, 2009).

Suatu proyek yang ideal adalah merupakan sesuatu yang baru dan asli, namun hal ini tidaklah mutlak bagi peserta didik. Peserta didik dapat pula bekerja dalam suatu proyek yang bertolak dari ide orang lain, tetapi kemudian mengadakan modifikasi dari dasar pemikiran tersebut. Peserta didik yang kreatif biasanya menghasilkan karya yang baru dan asli. Karya yang dihasilkan tersebut tentunya membutuhkan kemampuan berpikir kreatif, yaitu berpikir lancar, berpikir luwes, berpikir orisinal, dan berpikir elaborasi. Setiap model pembelajaran memiliki kelebihan dan kekurangan, termasik model pembelajaran berbasis proyek.

Menurut Boss dan Kraus yang dikutip oleh Abidin (2013) mengatakan bahwa kelebihan model pembelajaran berbasis proyek antara lain: (1) Model ini bersifat terpadu dengan kurikulum sehingga tidak memerlukan tambahan apapun dalam pelaksanaannya, (2) Peserta didik terlibat dalam kegiatan dunia nyata dan mempraktikkan strategi otentik secara disipin, (3) Peserta didik bekerja secara kolaboratif untuk memecahkan masalah yang penting baginya, (4) Teknologi terintegrasi sebagai alat untuk penemuan, kolaborasi, dan komunikasi dalam mencapai tujuan pembelajaran, (5) Meningkatkan kerja sama guru dalam merancang dan mengimplementasikan proyek-proyek yang melintasi batas-batas geografis atau bahkan melompat zona waktu. Selain memiliki kelebihan, model pembelajaran berbasis proyek juga memiliki kekurangan.

Kekurangan model pembelajaran berbasis proyek menurut Abidin (2013) yaitu sebagai berikut: (1) Memerlukan banyak waktu dan biaya, (2) Memerlukan banyak media dan sumber belajar, (3) Memerlukan guru dan peserta didik yang sama-sama siap belajar dan berkembang, (4) Ada kekhawatiran peserta didik hanya akan menguasai satu topik yang dikerjakannya. Menilik beberapa kelemahan tersebut, dalam konteks kurikulum 2013 penerapan ini tidak terlalu sulit. Hal ini disebabkan oleh kenyataan bahwa waktu belajar telah ditambah, media dan sumber belajar bisa

\section{Paris Langkis}

Vol.2 Nomor 1, Agustus 2021 
diperoleh darimana saja sehingga pembelajaran berbasis proyek dapat secara baik diimplementasikan dalam proses pembelajaran (Abidin, 2013).

Langkah-langkah pembelajaran berbasis proyek sebagaimana yang dikembangkan oleh The George Lucas Educational Foundation (2005) terdiri dari: (1) Penentuan pertanyaan mendasar, (2) Mendesain perencanaan proyek, (3) Menyusun jadwal, (4) Memonitor peserta didik dan kemajuan proyek, (5) Menguji hasil, dan (6) Mengevaluasi pengalaman.

\section{B. METODE PENELITIAN}

Metode dalam peneltian ini menggunakan metode quasi eksperimen dengan rancangan desain treatment by level $2 \times 2$ atau desain faktorial 2 X 2 . Hasil penelitian diambil dari uji hipotesis. Uji hipotesis dilakukan untuk mengetahui apakah hipotesis yang diajukan dalam penelitian ini diterima atau ditolak maka digunakan analysis of varian two ways (Anova dua jalur ).

\section{HASIL DAN PEMBAHASAN}

Uji Hipotesis untuk mengetahui apakah terdapat pengaruh interaksi antara model pembelajaran berbasis proyek dan kemampuan berpikir kritis terhadap hasil belajar PPKn di kelas VII SMP Negeri 11 Kota Serang.

Uji hipotesis dilakukan untuk mengetahui apakah hipotesis yang diajukan dalam penelitian ini diterima atau ditolak maka digunakan analysis of varian two ways ( Anova dua jalur ). Desain penelitian ini digunakan untuk meneliti dua variabel bebas atau lebih serta hubungan diantara variabel tersebut, hasil analisisnya adalah rasio $\mathrm{F}$ terpisah untuk setiap variabel bebas dan satu rasio F untuk interaksi.

Uji ini menggunakan uji $\mathrm{F}$, yaitu dengan membandingkan $\mathrm{F}_{\text {hitung }}$ dengan $\mathrm{F}_{\text {tabel }}$. Jika $\mathrm{F}_{\text {hitung }}<\mathrm{F}_{\text {tabel }}$ maka hipotesis tidak teruji variabel-variabel independen secara simultan tidak berpengaruh signifikan terhadap variabel dependen, dan jika $F_{\text {hitung }}>F_{\text {tabel }}$ maka hipotesis teruji yaitu variabel-variabel independen secara simultan berpengaruh signifikan terhadap variabel dependen.

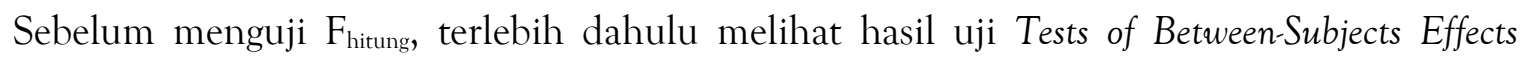
untuk melihat ada tidaknya interaksi antar variable. Hasil pengolahan data di dapat sebagai berikut :

Tabel Tests of Between-Subjects Effects SPSS

\begin{tabular}{|l|r|r|r|r|r|}
\hline \multicolumn{7}{|c|}{ Tests of Between-Subjects Effects } \\
\hline Dependent Variable: \\
\hline Source & $\begin{array}{l}\text { Type III } \\
\text { Sum of } \\
\text { Squares }\end{array}$ & df & $\begin{array}{c}\text { Mean } \\
\text { Square }\end{array}$ & F & Sig. \\
\hline $\begin{array}{l}\text { Corrected } \\
\text { Model }\end{array}$ & $4755.208^{\mathrm{a}}$ & 22 & 216,146 & 5,694 & 0,005 \\
\hline Intercept & 164858,349 & 1 & 164858,349 & 4342,610 & 0,000 \\
\hline Model & 748,818 & 4 & 187,204 & 4,931 & 0,022 \\
\hline $\begin{array}{l}\text { Kemampuan } \\
\text { Berpikir }\end{array}$ & 1523,714 & 8 & 190,464 & 5,017 & 0,013 \\
\hline
\end{tabular}

\section{Paris Langkis}

Vol.2 Nomor 1, Agustus 2021 


\begin{tabular}{|l|r|r|r|r|r|}
\hline $\begin{array}{l}\text { Model * } \\
\text { Kemampuan }\end{array}$ & 2259,356 & 9 & 251,040 & 6,613 & 0,005 \\
\hline Error & 341,667 & 9 & 37,963 & & \\
\hline Total & 234600,000 & 32 & & & \\
\hline Corrected Total & 5096,875 & 31 & & & \\
\hline
\end{tabular}

a. R Squared $=.933$ (Adjusted R Squared $=.769$ )

Tests of Between-Subject adalah output untuk uji hipotesis penelitian ini. Kolom pertama menunjukkan Faktor apa saja yang ada dalam penelitianini, kolom kedua menunjukkan jumlah kuadrat (JK), kolom ketiga menunjukkan derajat kebebasan (df), kolom ke empat menunjukkan ratarata kuadrat $(\mathrm{KT})$, kolom kelima menunjukkan Fhitung, dan kolom ke enam menunjukkan nilai signifikansi (Sig.).

Dasar pengambilan keputusan dalam uji ini adalah sebagai berikut:

1. Jika Nilai Signifikansi (sig.) lebih Kecil dari <0,05 maka artinya ada perbedaan hasil belajar berdasarkan variabel faktor.

2. Jika Nilai Signifikansi (sig.) lebih Besar dari $>0,05$ maka artinya tidak ada perbedaan hasil belajar berdasarkan variabel faktor.

Berdasarkan tabel di atas, didapatkan langkah dan Kesimpulan berdasarkan output diatas diperoleh nilai Signifikansi (sig.) sebesar 0,013 atau lebih kecil dari 0,05 maka artinya hipotesis yang menyatakan bahwa ada perbedaan Hasil Belajar PPKn berdasarkan Kemampuan Berpikir Kritis dapat diterima.

Untuk pengujian signifikasi, berdasarkan tabel di atas, didapatkan nilai $\mathrm{F}_{\text {hitung }}$ untuk masingmasing variabel lebih besar dari $F_{\text {tabel }}$ pada taraf signifikansi $5 \%$ dimana $F_{\text {tabel }}=4.091$ yang berarti dapat disimpulkan terdapat pengaruh secara signifikan interaksi antara model Pembelajaran Berbasis Proyek dan Kemampuan Berpikir Kritis peserta didik terhadap Hasil Belajar PPKn peserta didik.

\section{KESIMPULAN}

Terdapat pengaruh interaksi antara model pembelajaran berbasis proyek dan kemampuan berpikir kritis terhadap hasil belajar PPKn di kelas VII SMP Negeri 11 Kota Serang.

Berdasarkan tabel Tests of Between-Subjects Effects di atas, didapatkan Kesimpulan Sebagai Berikut : diperoleh nilai Signifikansi (sig.) sebesar 0,013 atau lebih kecil dari 0,05 maka artinya hipotesis yang menyatakan bahwa ada perbedaan Hasil Belajar PPKn berdasarkan Kemampuan Berpikir Kritis dapat diterima.

Untuk pengujian signifikasi, berdasarkan tabel Tests of Between-Subjects Effects di atas, didapatkan nilai $F_{\text {hitung }}$ untuk masing-masing variabel lebih besar dari $F_{\text {tabel }}$ pada taraf signifikansi $5 \%$ dimana $\mathrm{F}_{\text {tabel }}=4.091$ yang berarti dapat disimpulkan terdapat pengaruh secara signifikan interaksi antara model Pembelajaran Berbasis Proyek dan Kemampuan Berpikir Kritis peserta didik terhadap Hasil Belajar PPKn peserta didik.

\section{Paris Langkis}

Vol.2 Nomor 1, Agustus 2021 


\section{DAFTAR PUSTAKA}

Abidin, Yunus. (2013). Desain Sistem Pembelajaran Dalam Konteks Kurikulum 2013. Bandung: PT. Rafika Aditama

Adetya, A., Sakman, S., \& Saefulloh, A. (2021). Bentuk Pelaksanaan Ice Breaking Jenis

Storytelling Yang Dilakukan Oleh Guru Dalam Pembelajaran Ppkn Siswa Kelas Viii Di Smp

Kristen Palangka Raya. Aksara: Jurnal Ilmu Pendidikan Nonformal, 7(2), 577.

https://doi.org/10.37905/aksara.7.2.577-588.2021

Dewi Muryati; Endah Charolyna, Y., \& Ahmad Saefulloh. (2020). Kendala Alumni Prodi PPKn dalam Memperoleh Pekerjaan Serta Relevansinya dengan Kurikulum 2013 Dewi Muryati. 157-166. https://e-journal.upr.ac.id/index.php/JPN/article/view/2018

Hosnan. (2016). Pendekatan Saintifik dan Kontekstual dalam Pembelajaran Abad 21. Bogor: Ghalia Indonesia

Lana, D., \& Karliani, E. (2021). Pendekatan Pembelajaran Somatic Auditory Visual Intelegency (Savi) Dengan Menggunakan Media Video Pada Materi Dinamika .... Jurnal Paris Langkis, 1, 61-72. https://e-journal.upr.ac.id/index.php/parislangkis/article/view/2284

Pratama, D., \& Karakter, M. N. (2021). PROFESIONALITAS GURU MELALUI PENDEKATAN

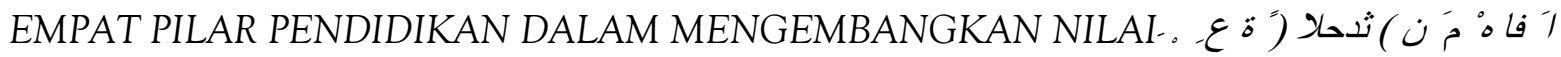

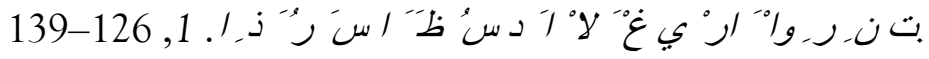

Joyce, Bruce \& Marsha Weil. 1980. Model of Teaching, Fifth Edition. USA: Allyn and Bacon A Simon \& Scuster Company.

Khamdi. 2007. Project Based Learning. Jakarta: Sejarah Indonesia.

\section{Paris Langkis}

Vol.2 Nomor 1, Agustus 2021 